\title{
Smart Server IOT Based Temperature Monitoring System
}

\author{
K.P.Kaliyamurthie, Nalini C., N.Priya, A.V.Allin Geo
}

\begin{abstract}
Internet of things is winding up increasingly more prevalent step by step because of its various focal points. Here expression Internet of Things proclaims a dream of things to come Internet where interfacing physical things. Albeit a significant part of the work has been done until today to comprehend the Internet of Things into complete, the vast majority of the work centers around asset obliged hubs, instead of connecting the current installed system[1] to the Internet of things organize. In this paper, we are building temperature based observing framework utilizing Internet of things for the server room.Here there is an application which will demonstrate the present temperature of the server room after every 2 seconds, and on the off chance that we need to change the temperature of the server room we can transform it as needs be. Here we are utilizing equipment perceived as raspberry pi for interfacing reason. Countries can gather the capability of this influx of advancement for assembling as well as for regularly life and work and the improvement of new data and administrations that will change the manner in which we get things done in numerous different backgrounds. Be that as it may, its prosperity isn't unsurprising. We have assessed our framework and demonstrated that our system can be utilized successfully to incorporate functional Internet of things applications over existingsystem.
\end{abstract}

\section{Watchwords : OT, GPIO, Raspberry Pi}

\section{INTRODUCTION}

The Internet is a living entity, always altering and evolving. New applications and businesses are created continuously. In addition to an developing Internet, technology is also changing the landscape. The Internet of Things is driven by a growth of the Internet through the inclusion of physical objects combined with an ability to provide better efficiency to the environment as more data becomes available. [1][2]

We are entering a new age of technology that is Internet of Things. Machine to machine, machine to environment, the Internet of the Internet of things technology is referred in our temperature based monitoring system, and it has been an expanding. Technology [11]to[19] at which it provides a platform to enhance the system. Whole thing, the Internet of

Revised Manuscript Received on July 22, 2019

K.P.Kaliyamurthie, Department of Computer Science and Engineering, Bharath Institute of Higher Education and Research, Chennai. Email: kpkaliyamurthie@gmail.com

Nalini C., Department of Computer Science and Engineering, Bharath Institute of Higher Education and Research, Chennai. Email: nalinicha2002@gmail.com

N.Priya, Department of Computer Science and Engineering, Bharath Institute of Higher Education and Research, Chennai. Email: priyabiher@gmail.com

A.V.Allin Geo, Department of Computer Science and Engineering, Bharath Institute of Higher Education and Research, Chennai. Email: seemeallin@gmail.com smart Things, intelligent system call it what you want, but it's occurrence, and its possible is vast. We see the internet of things as billions of smart, connected "things", that will include every feature of our life, and its foundation is the intelligence that embedded giving out provides. The internet of things is comprised of elegant.

\section{LITERATURE SURVEY}

Web of Things speaks to a typical idea for the ability of system plans to keenness and gather information from the world about us, and after that split that information crossways the Internet where it tends to be process and used for different alluring reason. Numerous organizations on the planet have issue to know the genuine state of the machine. The motivation to know the state of the machine is to make the anticipation and to evade the machine from breakdown, so this task is creating to screen the temperature sensor framework. A great deal of work has been completed for observing temperature sensor. Latest work is toward creating Wireless sensor for temperature checking machines collaborating and imparting [20] with extra machines, substance, condition and foundations. As an outcome, immense volumes of data are being produced, and that realities is being prepared into reasonable occasions that can "expert and oversee" things to make our life a lot simpler and more secure and to Decrease our contact on the environment.[21] tp[30]

The center thought is to interface temperature sensor with Raspberry Pi gather the temperature readings and show those readings on the cell phone. Likewise we would utilize $h$ adoop bunch to spare all the temperature changes. These temperature chronicles perhaps utilized for investigation later on. We will put the Raspberry $\mathrm{Pi}$ and the temperature sensor at Neova's server room and read current temperature utilizing Cool Server Room application on the cell phone essentially, we are building an application which will demonstrate the insights and current temperature of the server room.[31] to [40]

The SAP solutions[4] for the Internet of Things give all you have to make information driven knowledge from related impacts, natives and plans. Associate your business with the new generation of Internet empower designs in the cloud, convert your current business procedure and reconsider your industry and client experience. In execution of framework when we recover the present temperature readings and show 
those readings on the cell phone. Additionally we would utilize Hadoop bunch to keep every glow change. These hotness recording possibly utilized for concentrate later on. We will put the Raspberry Pi and the temperature sensor at Neova's server room and read current temperature utilizing Cool ServerRoom[5] application on the cell phone essentially, we are building an application which will demonstrate the measurements and current temperature of the server room utilizing Fig: 1.

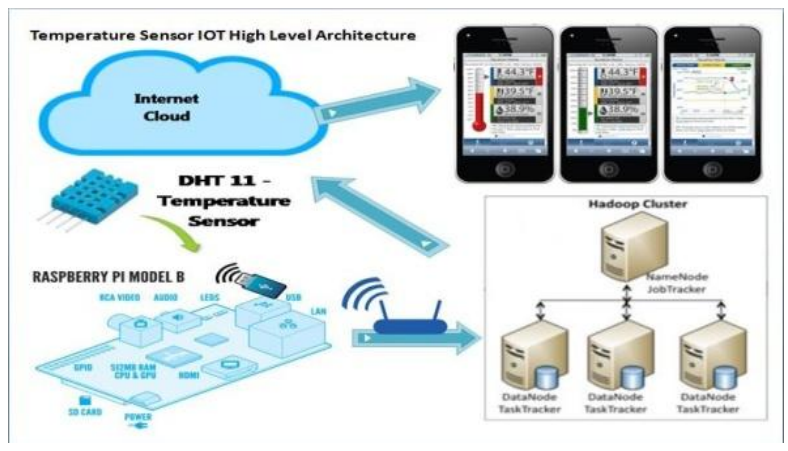

Fig1.System Architecture

In server room, there will be a temperature sensor installed on raspberry pi kit. Raspberry pi will have node js installed on it which will allow the raspberry pi kit to read data on temperature sensor and it will push it to the Hadoop and cloud. There will be Cloud VM which will again have node js installed on it but it will also have sails js (a MVC framework) which will act as server for your mobile app. Sails js server (cloud vm) will provide data to mobile app which it has received from raspberry pi kit. The mobile app will be developed by angular js's framework ionic which will just give you an idea in relation to the data from sails js sever. When the system just connects to the internet, the quick and important is displayed on the screen of device[41].

\section{A. Actual system}

In the server room, there will be a temperature sensor installed on raspberry pi kit. Raspberry pi will have node js installed on it which will allow the raspberry pi kit to read data on temperature sensor and it will push it to the hadoop and cloud. There will be Cloud VM which will again have node js installed on it but it will also have sails js (a MVC framework) which will act as server for your mobile app. Sails js server (cloud vm) [29] will provide data to mobile app which it has received from raspberry pi kit. The mobile app will be developed by angular js's framework ionic which will just show the data from sails js sever by Fig:2.

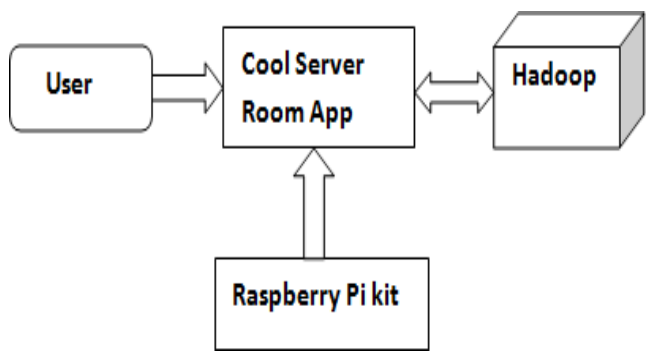

Figure 2 System Implementation

\section{III.CONCLUSION}

As per the paper I conclude that SAP solutions for the Internet of Things give the whole thing you need to generate data-driven intellect from connected things, people and devices[8]. join your industry with the new generation of Internet-and transform your existing business processes and reimaging your commerce and client experience. And in the future it can be used for European countries where the temperature is always cold; therefore in home level it can be used. As there is always cold, there is a need to on the heater of the room, so here everything can be done automatically[9].

\section{REFERENCES}

[1] Kumaravel A., Rangarajan K.,Algorithm for automaton specification for exploring dynamic labyrinths,Indian Journal of Science and Technology,V-6,I-SUPPL5,PP-4554-4559,Y-2013

[2] P. Kavitha, S. Prabakaran "A Novel Hybrid Segmentation Method with Particle Swarm Optimization and Fuzzy C-Mean Based On Partitioning the Image for Detecting Lung Cancer" International Journal of Engineering and Advanced Technology (IJEAT) ISSN: 2249-8958, Volume-8 Issue-5, June 2019

[3] Kumaravel A., Meetei O.N.,An application of non-uniform cellular automata for efficient cryptography,2013 IEEE Conference on Information and Communication Technologies, ICT 2013,V-,I-,PP-1200-1205,Y-2013

[4] Kumarave A., Rangarajan K.,Routing alogrithm over semi-regular tessellations,2013 IEEE Conference on Information and Communication Technologies, ICT 2013,V-,I-,PP-1180-1184,Y-2013

[5] P. Kavitha, S. Prabakaran "Designing a Feature Vector for Statistical Texture Analysis of Brain Tumor" International Journal of Engineering and Advanced Technology (IJEAT) ISSN: 2249-8958, Volume-8 Issue-5, June 2019

[6] Dutta P., Kumaravel A.,A novel approach to trust based identification of leaders in social networks, Indian Journal of Science and Technology,V-9,I-10,PP--,Y-2016

[7] Kumaravel A., Dutta P.,Application of Pca for context selection for collaborative filtering,Middle - East Journal of Scientific Research,V-20,I-1,PP-88-93,Y-2014

[8] Kumaravel A., Rangarajan K.,Constructing an automaton for exploring dynamic labyrinths,2012 International Conference on Radar, Communication and Computing, ICRCC 2012,V-,I-,PP-161-165,Y-2012

[9] P. Kavitha, S. Prabakaran "Adaptive Bilateral Filter for Multi-Resolution in Brain Tumor Recognition” International Journal of Innovative Technology and Exploring Engineering (IJTTEE) ISSN: 2278-3075, Volume-8 Issue-8 June, 2019

[10] Kumaravel A.,Comparison of two multi-classification approaches for detecting network attacks, World Applied Sciences Journal,V-27,I-11,PP-1461-1465,Y-2013

[11]Tariq J., Kumaravel A.,Construction of cellular automata over hexagonal and triangular tessellations for path planning of multi-robots,2016 IEEE International Conference on Computational Intelligence and Computing Research, ICCIC 2016,V-,I-,PP--,Y-2017

[12] Sudha M., Kumaravel A.,Analysis and measurement of wave guides using poisson method,Indonesian Journal of Electrical Engineering and Computer Science,V-8,I-2,PP-546-548,Y-2017

[13] Ayyappan G., Nalini C., Kumaravel A., Various approaches of knowledge transfer in academic social network,International Journal of Engineering and Technology,V-,I-,PP-2791-2794,Y-2017

[14] Kaliyamurthie, K.P., Sivaraman, K., Ramesh, S. Imposing patient data privacy in wireless medical sensor networks through homomorphic cryptosystems 2016, Journal of Chemical and Pharmaceutical Sciences92.

[15] Kaliyamurthie, K.P., Balasubramanian, P.C. An approach to multi secure to historical malformed documents using integer ripple transfiguration 2016 Journal of Chemical and Pharmaceutical Sciences92. 
[16]A.Sangeetha,C.Nalini,"Semantic Ranking based on keywords extractions in the web", International Journal of Engineering \& Technology, 7 (2.6) (2018) 290-292

[17] S.V.GayathiriDevi,C.Nalini,N.Kumar,"An efficient software verification using multi-layered software verification tool "International Journal of Engineering \& Technology, 7(2.21)2018 454-457

[18]C.Nalini,ShwtambariKharabe,"A Comparative Study On Different Techniques Used For Finger - Vein Authentication”, International Journal Of Pure And Applied Mathematics, Volume 116 No. 82017 , 327-333, Issn: 1314-3395

[19]M.S. Vivekanandan and Dr. C. Rajabhushanam, "Enabling Privacy Protection and Content Assurance in Geo-Social Networks", International Journal of Innovative Research in Management, Engineering and Technology, Vol 3, Issue 4, pp. 49-55, April 2018.

[20]Dr. C. Rajabhushanam, V. Karthik, and G. Vivek, "Elasticity in Cloud Computing", International Journal of Innovative Research in Management, Engineering and Technology, Vol 3, Issue 4, pp. 104-111, April 2018.

[21]K. Rangaswamy and Dr. C. Rajabhushanamc, "CCN-Based Congestion Control Mechanism In Dynamic Networks", International Journal of Innovative Research in Management, Engineering and Technology, Vol 3, Issue 4, pp. 117-119, April 2018.

[22] Kavitha, R., Nedunchelian, R., "Domain-specific Search engine optimization using healthcare ontology and a neural network backpropagation approach", 2017, Research Journal of Biotechnology, Special Issue 2:157-166

[23] Kavitha, G., Kavitha, R., "An analysis to improve throughput of high-power hubs in mobile ad hoc network" , 2016, Journal of Chemical and Pharmaceutical Sciences, Vol-9, Issue-2: 361-363

[24] Kavitha, G., Kavitha, R., "Dipping interference to supplement throughput in MANET" , 2016, Journal of Chemical and Pharmaceutical Sciences, Vol-9, Issue-2: 357-360

[25] Michael, G., Chandrasekar, A.,'Leader election based malicious detection and response system in MANET using mechanism design approach", Journal of Chemical and Pharmaceutical Sciences(JCPS) Volume 9 Issue 2, April - June 2016

[26]Michael, G., Chandrasekar, A.,"Modeling of detection of camouflaging worm using epidemic dynamic model and power spectral density", Journal of Chemical and Pharmaceutical Sciences(JCPS) Volume 9 Issue 2, April - June 2016.

[27]Pothumani, S., Sriram, M., Sridhar, J., Arul Selvan, G., Secure mobile agents communication on intranet,Journal of Chemical and Pharmaceutical Sciences, volume 9, Issue 3, Pg No S32-S35, 2016

[28] Pothumani, S., Sriram, M., Sridhar, Various schemes for database encryption-a survey, Journal of Chemical and Pharmaceutical Sciences, volume 9, Issue 3, Pg NoS103-S106, 2016

[29]Pothumani, S., Sriram, M., Sridhar, A novel economic framework for cloud and grid computing, Journal of Chemical and Pharmaceutical Sciences, volume 9, Issue 3, Pg No S29-S31, 2016

[30] Priya, N., Sridhar, J., Sriram, M. "Ecommerce Transaction Security Challenges and Prevention Methods- New Approach” 2016 ,Journal of Chemical and Pharmaceutical Sciences, JCPS Volume 9 Issue 3.page no:S66-S68

[31] Priya, N.,Sridhar,J.,Sriram, M."Vehicular cloud computing security issues and solutions" Journal of Chemical and Pharmaceutical Sciences(JCPS) Volume 9 Issue 2, April - June 2016

[32] Priya, N., Sridhar, J., Sriram, M. "Mobile large data storage security in cloud computing environment-a new approach" JCPS Volume 9 Issue 2. April - June 2016

[33] Anuradha.C, Khanna.V, "Improving network performance and security in WSN using decentralized hypothesis testing "Journal of Chemical and Pharmaceutical Sciences(JCPS) Volume 9 Issue 2, April - June 2016 .

[34] Anuradha.C, Khanna.V, "A novel gsm based control for e-devices" Journal of Chemical and Pharmaceutical Sciences(JCPS) Volume 9 Issue 2, April - June 2016 .

[35] Anuradha.C, Khanna.V, "Secured privacy preserving sharing and data integration in mobile web environments " Journal of Chemical and Pharmaceutical Sciences(JCPS) Volume 9 Issue 2, April - June 2016.

[36]Sundarraj, B., Kaliyamurthie, K.P. Social network analysis for decisive the ultimate classification from the ensemble to boost accuracy rates 2016 International Journal of Pharmacy and Technology
[37] Sundarraj, B., Kaliyamurthie, K.P. A content-based spam filtering approach victimisation artificial neural networks 2016 International Journal of Pharmacy and Technology83.

[38] Sundarraj, B., Kaliyamurthie, K.P. Remote sensing imaging for satellite image segmentation 2016 International Journal of Pharmacy and Technology8 3.

[39] Sivaraman, K., Senthil, M. Intuitive driver proxy control using artificial intelligence 2016 International Journal of Pharmacy and Technology84.

[40] Sivaraman, K., Kaliyamurthie, K.P. Cloud computing in mobile technology 2016 Journal of Chemical and Pharmaceutical Sciences92.

[41] Sivaraman, K., Khanna, V. Implementation of an extension for browser to detect vulnerable elements on web pages and avoid click jacking 2016 Journal of Chemical and Pharmaceutical Sciences92.

\section{AUTHORS PROFILE}

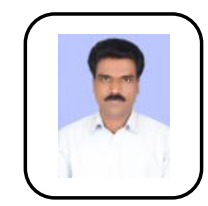

K.P.Kaliyamurthie, Professor, Department of Computer Science \& Engineering, Bharath Institute of Higher Education and Research, Chennai, India

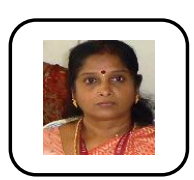

Nalini C, Assistant Professor, Department of Computer Science \& Engineering, Bharath Institute of Higher Education and Research, Chennai, India

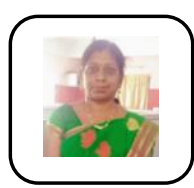

N.Priya, Assistant Professor, Department of Computer Science \& Engineering, Bharath Institute of Higher Education and Research, Chennai, India

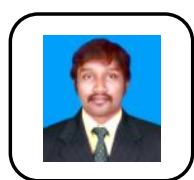

A.V.Allin Geo, Assistant Professor, Department of Computer Science \& Engineering, Bharath Institute of Higher Education and Research, Chennai, India 